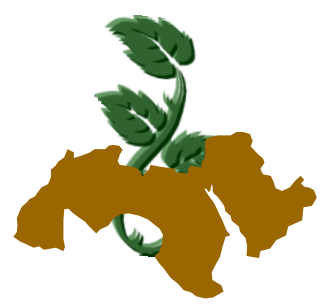

Arab Univ.

\title{
RESPONSE OF GROUNDNUT TO INTERCROPPING WITH SOME SESAME VARIETIES UNDER DEFERENT PLANT DENSITY
}

\author{
Abou-Kerisha1, M.A.; R.A. Gadallah ${ }^{1}$ and E.E.A. Mohamdain ${ }^{1}$ \\ 1- Crop Intensification Research Department, Field Crop Research Institute Agricultural \\ Research Center, Giza, Egypt
}

Keywords: Sesame planting density, Groundnut, Intercropping, Competitive relationships

\section{ABSTRACT}

Two field trials were carried out at Shandaweel Research Station (Sohag governorate) during 2005 and 2006 summer seasons to investigate the response of groundnut to intercropping with three sesame varieties under different plant densities in relation to yield and yield component of both crops. A split plot design with three replicates was used. The main plots were devoted to sesame varieties (Shandaweel 3, Toshka 1 and Giza 32) while the sub plots were devoted for plant densities $(100 \%$, $67 \%$ and $50 \%$ representing three hill spacing of sesame i.e. 20,30 and $40 \mathrm{~cm}$. respectively). The groundnut (the main crop) was grown on all ridges at a normal plant density. The data obtained indicate that all studied traits of groundnut were decreased when intercropping with sesame varieties as compared with solid crops. This reduction was higher when intercropped with sesame cv Giza 32 than with the other sesame varieties. Yield and yield components of groundnut were also significantly affected by the plant densities of sesame varieties. The yield of groundnut when intercropped with low sesame density $(50 \%)$ exceeded that with high density of sesame $(100 \%)$ by 31.66 , 27.51 and $29.53 \%$ in the first, the second and the combined of the two seasons respectively. The results also indicated that yields of all sesame varieties were decreased under intercropping condition. Sesame Giza 32 variety surpassed the other varieties (Shandaweel 3 and Toshka 1) in plant height, number of branches, number of capsules / plant, seed yield / plant and seed yield / fad. The high plant density $(100 \%)$ recorded the highest sesame seed yield / fad. where the increase was
46.93 and $13.50 \%$ in the first season, 2.46 and $8.71 \%$ in the second season and 25.86 and $11.19 \%$ in the combined data over the low and medium density treatments, respectively. The response equations of pod yield / fad. of groundnut was linear with each decrease of sesame planting density and with higher magnitude under Toshka 1 than under the other to sesame varieties. The treatment of groundnut with Toshka 1 under low density had higher land equivalent ratio (LER) (1.41), intercropping advantage (IA) (582.8) and monetary advantage index (MAI) (1666.85). The treatment of groundnut with Giza 32 under low density had higher actual yield loss (AYL) (+1.245). It could be concluded that intercropping groundnut with Toshka 1 under medium density had favoured the growth and yield of both crops.

\section{INTRODUCTION}

Groundnut and sesame are of the major oil seed crops in the world as well as in Egypt. These crops are grown not only for oil production but also for fresh human consumption or for export. Intercropping oil seed crops are an avenue of approach to increase the net return of the land in desert areas through increasing land use efficiency by intercropping system.

Several investigations reported that number of pods per plant was found to be the most important trait as contributor to yield in groundnut. It had a positive relationship with yield per plant, but it had a negative correlation with 100 -pod weight while, 100 -pod weight had positive correlation with 100seed weight. (Salame et al 1981). El-Mihi et al (1990) found that intercropping sesame with groundnut had positive effect on land equivalent ratio which was more than one. Aggressivity value in general was positive for sesame whereas 
groundnut was the dominated. Gabr (1999) found that groundnut intercropped with sesame at $1: 1$ row ratio produced lower yield than its pure stand with various combinations. Groundnut pod yield was the highest when grown at $100 \%$ plant densities whereas seed yield was the highest at $50 \%$ of recommended plant densities. Therefore LER was the highest when groundnut and sesame were intercropped at $1: 1$ row ratio with $100 \%$ and $50 \%$ plant densities groundnut and sesame respectively. Sarkar and Sanyal (2000) noted that an intercropped of groundnut with sesame was found most beneficial compared to sole stand sesame. Sesame + groundnut under 3:2 row proportion gave the maximum sesame- equivalent yield (947 kg/ ha), land equivalent ratio (1.31), product of relative crowding coefficient ( $\mathrm{K} 3.87$ ), monetary advantage (Rs, 2.913 / ha) net returns (Rs, 5.321 / ha) income equivalent ratio (1.21) and also indicated a modest competitive ratio $(0.86: 1.16)$ and aggressivity factor ( \pm 0.37). Badran (2002) found that groundnut was dominant intercrop component while sesame was the dominated one under the studied intercropping system, with the exception of early planting of sesame followed by planting groundnut. Toaima et al (2004) found that growth, yield components and total yield of peanut and sesame were significantly affected by intercropping patterns. Intercropping sesame and peanut in 2:2 patterns produced the highest yield for peanut and sesame, compared with the other intercropping patterns. Bhatti et al (2006) reported that the sesame grown in association with different grain legumes i.e. mungbean, mash bean, soybean and cowpea) appeared to be a dominant crop as indicated by its higher values of relative crowding coefficient, competitive ratio and positive sign of aggressivity.

The effect of plant population of sesame on yield and yield components had been reported by several workers. Seed yield per unit area increased with increasing population density from 80.000 to 160.000 plants / ha beyond this density it becomes counter productive. (Delgado and Yamonos, 1975). Also, Channabasavanna and Setty (1992) found that seed yields of two sesame varieties were significantly higher with 666,666 plants / ha compared with 222,222 plants / ha. due the increase in the capsules / $\mathrm{m}^{2}$ though the number of branches / plant and capsules / plant were higher in the low density. Morever, Chimanshette and Dhoble (1992) reported that the plant density of 222,000 plants / ha $(45 \mathrm{~cm} \times 100 \mathrm{~m})$ recorded significantly higher seed yield $(364 \mathrm{~kg} / \mathrm{ha})$ than lower plant densities. The seed yield decreased significantly with the decrease in plant density from 222,000 to 111,000 plant density of both sesame varieties. Furthermore, Ghungarde et al (1992) and Dhoble et al (1993) showed that sesame seed yield / plant was higher at lower plant density where it was curvilinearly decreased with an increase in plant density, but the seed yield /ha was however, increased asymptotically. They added that the competition- freeness index declined with increase in plant density. Ghosh and Patra (1994) showed that high plant density $(333,000 /$ ha) recorded higher seed yield and greater harvest index and higher oil yield than the low plant densities. It also paid high net return along with high return / rupee invested. El-Serogy et al (1997) showed that the B.35 sesame variety surpassed Giza 32 in plant height and first capsule height, while Giza 32 surpassed B.35 in number of capsules/ plant and seed weight / plant, 1000-seed weight and seed yield / fad. The highest values for number of capsules / plant, seed yield/ plant and 1000-seed weight were recorded from plants sown on ridges $70 \mathrm{~cm}$. apart with $10 \mathrm{~cm}$. between hills while the highest seed yield / fad was produced by growing sesame plants on ridges $50 \times 10 \mathrm{~cm}$. on one side or $60 \times 20 \mathrm{~cm}$. on the two sides of ridges. Ghosh (2004) found that LER was higher there is also significant economic benefit expressed with higher MAL values when grown groundnut with cereal fodder intercropping systems. Sherif Sahar et al (2005) found that the number of pods / plant, pods weight / plant, 100 seed weight and pods yield / fad of groundnut were increased when intercropped with maize grown plants at $100 \mathrm{~cm}$. apart than when maize plants were oriented at $50 \mathrm{~cm}$. ElSawy et al (2006) showed that intercropping system of $100 \%$ peanut $+25 \%$ sunflower gave the highest significant values for yield and yield components of both crops. While intercropping system of $100 \%$ peanut $+100 \%$ sunflower produced higher land equivalent ratio (1.67). Rahnama and Bakhshandedh (2006) found significant effect on the yield components due to an increase in sesame row-spacing. They indicated that the increase in plant spacing from 5 to $20 \mathrm{~cm}$. caused a decrease in stem height but caused an increase in stem diameter and pod number per plant. Abd ElZaher et al (2007) recorded that intercropping systems of $100 \%$ peanut $+33 \%$ maize gave the highest total yield, followed by $100 \%$ peanut $+50 \%$ maize, whereas the lowest value was obtained with $100 \%$ peanut $+67 \%$ maize intercropping.

\section{MATERIALS AND METHODS}


Two field trails were carried out at Shandaweel Agric. Res. Sta., Sohag governorate (Upper Egypt) during the summer 2005 and 2006 seasons. The objective of this study was to investigate the response of groundnut to intercropping with three sesame grown varieties under different plant densities in relation to yield and yield components of both crops. The groundnut (the main crop) was grown on all ridges at (normal density).

A split plot design with three replicates was used. The main plots were devoted to three sesame varieties i.e. Shandaweel 3, Toshka 1 and Giza 32 whereas the sub plots were allocated for three hill spacing of sesame which were 20,30 and $40 \mathrm{~cm}$. The area of each sub plot was $24 \mathrm{~m}^{2}(6 \mathrm{~m}$. wide $\times 4 \mathrm{~m}$. long), consisting of ten ridges. Groundnut was grown on one side of all ridges in one plant / hill $10 \mathrm{~cm}$. apart $(70,000$ plant / fad) and sesame was planted on the other side of ridges with two plants / hill in (Table 1).

Pure stand for groundnut and sesame was included for comparison. Groundnut was sown in the first week of May while sesame was sown in third week of May during the two seasons. During seedbed preparation, $30 \mathrm{~kg} \mathrm{P}_{2} \mathrm{O}_{2} /$ fad in the form of calcium superphosphate $\left(\begin{array}{lll}15.5 \% & \left.\mathrm{P}_{2} \mathrm{O}_{5}\right)\end{array}\right)$ was added. Nitrogen fertilizer was used at the rate of $30 \mathrm{~kg} \mathrm{~N} /$ fad for groundnut and $15 \mathrm{~kg} /$ fad for sesame in the form of ammonium sulfate $(20.5 / \mathrm{N})$ in two equal doses. The first dose was added after thinning and the second at one month later. Potassium fertilizer was added at the rate of $50 \mathrm{~kg} / \mathrm{fad}$ for groundnut and $25 \mathrm{~kg} /$ fad for sesame in one dose with the first dose of nitrogen in the form of potassium sulfate $\left(48 \% \mathrm{~K}_{2} \mathrm{O}\right)$.

Harvesting took place in the first week and the later week of Sep. for sesame and groundnut respectively in both seasons. At harvest, samples of ten plants each were taken from each sub plot and the following data were recorded on growth and yield components of the two component crops.

Sesame data: Plant height (cm.), number of branches / plant, number of capsules / plant, seed index (g), seed yield / plant (g) and seed yield / fad. (ardab = $120 \mathrm{~kg}$.).

Groundnut data: Plant height $(\mathrm{cm}$.), number of pods/ plant, seed index (g), pod yield / plant (g) and pod yield $/$ fad. (ardab = $75 \mathrm{~kg}$.).

\section{Land equivalent ratio (LER)}

LER is determined as the sum of the fractions of the yield of intercrops relative to their sole crop yields (Willey and Osiru 1972). Land equivalent ratio LER was determined according to the following formula:

$$
\text { LER }=\frac{Y a b}{Y a a}+\frac{Y b a}{Y b b}
$$

Where: Yaa is pure stand yield of species a, Ybb is pure stand yield of species $b, Y a b$ is mixture yield of a (when combined with $b$ ) and Yba yield of $\mathrm{b}$ (when combined with $\mathrm{a}$ ).

\section{Aggressivity ( Agg )}

This was proposed by Mc-Gilichrist (1960) and was determined according to the following formula.

$$
A a b=\frac{y a b}{y a a \times z a b}-\frac{y b a}{y b b \times z b a}
$$

An aggressivity value of zero indicates that the component crops are equally competitive. For any other situation both crops will have the same numerical value, but, the sign of the dominate crop will be positive and the dominated negative. The greater the numerical value of (Agg), the bigger the difference in competitive abilities and the bigger the difference between actual and expected yields.

3. Competitive ratio (CR) was calculated by following the formula as advocated by Willey and Rao (1980)

$$
\mathrm{CR}=\mathrm{CRa}+\mathrm{CRb} \quad \mathrm{CRa}=\left\{\left(\frac{L E R a}{L E R b}\right) \times\left(\frac{Z b a}{Z a b}\right)\right\},
$$

Where: LERa and LERb represent relative yield of $a$ and $b$ intercrops, respectively. Since the CR values of the two crops will in fact be reciprocals of each other.

$\mathrm{CRa}, \mathrm{CRb}$ are the competitive ratio for intercrop where Zab representing the sown proportion of intercrop a (sesame) in combination with b (groundnut) and Zba the sown proportion of intercrop b (groundnut) in combination with a (sesame).

\section{Competitive relationships}


Table 1 . Plant populations of both groundnut and sesame in different rectangular ties system

\begin{tabular}{|c|cc|cc|}
\hline \multirow{2}{*}{ Treatment } & \multicolumn{2}{|c|}{ Rectangularity } & \multicolumn{2}{c|}{ Population / fad. } \\
\cline { 2 - 5 } & Groundnut & Sesame & Groundnut & Sesame \\
\hline Sole & $60 \times 10 \mathrm{~cm}$ & $60 \times 20 \mathrm{~cm}$ & 70.000 & 70.000 \\
Plant density in the intercrop & & & & \\
$\mathrm{S}_{1}$ & & $60 \times 20 \mathrm{~cm}$ & 70.000 & $70.000(100 \%)$ \\
$\mathrm{S}_{2}$ & & $60 \times 30 \mathrm{~cm}$ & 70.000 & $46.666(67 \%)$ \\
$\mathrm{S}_{3}$ & & $60 \times 40 \mathrm{~cm}$ & 70.000 & $35.000(50 \%)$ \\
\hline
\end{tabular}

4. Actual yield loss (AYL) was calculated as according to (Banik, 1996) as follows:

$$
\begin{aligned}
A Y L & =A Y L a+A Y L b \\
& =\left[\left\{\frac{(Y a b / Z a b)}{(\text { Yaa/Zaa })}\right\}-1\right]+\left[\left\{\frac{(Y b a / Z b a)}{(Y b b / Z b b}\right\}-1\right] .
\end{aligned}
$$

Where: AYLa and AYLb are the partial yield loss of intercrop sesame and groundnut respectively.

Yab representing the yield of intercrop a (sesame) in combination with $b$ (groundnut), Yba the yield of intercrop $b$ (groundnut) in combination with a (sesame).

5. Intercropping advantage (I A) was calculated using the following formula (Banik et al 2000):

IA sesame $=$ AYL sesame $\times$ Price sesame IA groundnut $=$ AYL groundnut $\times$ Price ground nut

The market price of average the two seasons for sesame and groundnut were $600 \mathrm{LE} /$ ardab and 400 LE / ardab respectively.

6. Monetary advantage index (MAI): suggests that the economic assessment should be in terms of the value of land saved; this could probably be most assessed on the basis of the rentable value of this land. MAI was calculated according to the formula, suggested by Willey (1979).

MAI $=\frac{\text { Value of combined intercrops } \times L E R-1}{L E R}$

The data for each experiment were then analyzed by MSTATC software for comparison of the mean values and the two seasons by LSD test at the $5 \%$ level. Response equations were calculated according to Snedecor and Cochran (1988) or explained by Abdul-Galil et al (2000 b).

\section{RESULTS AND DISCUSSION}

\section{I- Groundnut response}

\section{Sesame varietals differences effect}

Data presented in Table (2) showed that sesame varieties had significant effects on growth, yield and yield components of groundnut (the main crop) in both seasons and the combined data of both seasons. Data indicated that plant height and number of branches / plant of groundnut were decreased when intercropped with any sesame variety as compared by solid but with more adverse effect with cv Giza 32 compared with those intercropped by the other two varieties. These results were true in both seasons. Yield and yield components were also significantly decreased by sesame varieties. These decreases were high with cv Giza 32 the combined data. The reduction due to intercropping with cv Shandaweel 3 was $31.28 \%$ for number of pods / plant, $5.06 \%$ for seed index, $55.46 \%$ for pods yield / plant and $40.55 \%$ for pods yield / fad as compared with the solid the combined of the two seasons. This reduction with cv Toshka 1 was $32.14 \%$ for number of pods/ plant, $11.82 \%$ for seed index, $60.82 \%$ for pods yield / plant and $34.76 \%$ for pods yield / fad. While when intercropping with cv Giza 32 was $35.89 \%$ for number of pods / plant, $12.43 \%$ for seed index $66.15 \%$ for pod yield / plant and $49.71 \%$ for pod yield / fad. on the same order. Based on these results, it seemed that yield and yield components of groundnut were truely affected by sesame varieties. The more branched sesame variety Giza 32 with latter plants more shading to might have had caused groundnut intercrop which resulted in substantially reduced yield and yield components due to a low amount of light intercepted. It could be 
Table 2. Effect of sesame varieties on yield and yield components of groundnut in the two seasons and their combined data

\begin{tabular}{|c|c|c|c|c|c|c|}
\hline Varieties & $\begin{array}{l}\text { Plant } \\
\text { height } \\
\text { (cm.) }\end{array}$ & $\begin{array}{c}\text { No. of } \\
\text { branches / } \\
\text { plant }\end{array}$ & $\begin{array}{l}\text { No. of pods } \\
\text { / plant }\end{array}$ & $\begin{array}{c}\text { Seed } \\
\text { index }(g)\end{array}$ & $\begin{array}{l}\text { Pod yield / } \\
\text { plant (g) }\end{array}$ & $\begin{array}{l}\text { Pod yield / } \\
\text { fad (ar- } \\
\text { dab) }\end{array}$ \\
\hline \multicolumn{7}{|c|}{ First season } \\
\hline $\begin{array}{c}\text { A }_{1} \text { Shandaweel } 3 \\
\text { A }_{2} \text { Toshka } 1 \\
\text { A }_{3} \text { Giza } 32 \\
\text { LSD } \\
\text { C.V. } \\
\text { Solid first season }\end{array}$ & $\begin{array}{c}49.91 \\
47.73 \\
46.60 \\
1.63 \\
2.59 \\
56.67 \\
\end{array}$ & $\begin{array}{c}9.33 \\
10.29 \\
8.20 \\
1.49 \\
1.23 \\
12.80 \\
\end{array}$ & $\begin{array}{c}26.95 \\
26.64 \\
24.53 \\
0.34 \\
1.01 \\
42.20 \\
\end{array}$ & $\begin{array}{c}74.05 \\
68.71 \\
68.08 \\
2.75 \\
2.99 \\
78.97 \\
\end{array}$ & $\begin{array}{c}34.56 \\
28.44 \\
22.89 \\
1.22 \\
3.26 \\
73.00 \\
\end{array}$ & $\begin{array}{c}6.97 \\
7.29 \\
5.72 \\
0.18 \\
2.01 \\
10.92 \\
\end{array}$ \\
\hline \multicolumn{7}{|c|}{ Second season } \\
\hline $\begin{array}{c}A_{1} \text { Shandaweel } 3 \\
A_{2} \text { Toshka } 1 \\
A_{3} \text { Giza } 32 \\
\text { LSD } \\
\text { C.V. } \\
\text { Solid second } \\
\text { season }\end{array}$ & $\begin{array}{c}49.42 \\
49.40 \\
46.00 \\
1.51 \\
2.64 \\
61.00\end{array}$ & $\begin{array}{c}10.18 \\
11.22 \\
9.42 \\
0.74 \\
5.52 \\
13.33\end{array}$ & $\begin{array}{c}32.38 \\
31.93 \\
30.80 \\
1.11 \\
2.68 \\
44.13\end{array}$ & $\begin{array}{c}73.82 \\
68.53 \\
67.99 \\
3.40 \\
3.71 \\
76.73\end{array}$ & $\begin{array}{c}36.56 \\
34.11 \\
31.14 \\
1.06 \\
2.38 \\
86.67\end{array}$ & $\begin{array}{r}7.19 \\
8.25 \\
6.25 \\
0.34 \\
3.58 \\
12.90\end{array}$ \\
\hline \multicolumn{7}{|c|}{ Combined data of the two seasons } \\
\hline $\begin{array}{c}\text { A }_{1} \text { Shandaweel } 3 \\
\text { A }_{2} \text { Toshka } 1 \\
\text { A }_{3} \text { Giza } 32 \\
\text { LSD } \\
\text { C.V. } \\
\text { Solid combined } \\
\text { seasons }\end{array}$ & $\begin{array}{c}49.66 \\
48.57 \\
46.30 \\
0.92 \\
2.48 \\
58.83\end{array}$ & $\begin{array}{c}9.76 \\
10.76 \\
8.81 \\
0.31 \\
4.18 \\
13.00\end{array}$ & $\begin{array}{c}29.66 \\
29.29 \\
27.67 \\
0.48 \\
2.18 \\
43.16\end{array}$ & $\begin{array}{c}73.94 \\
68.62 \\
68.20 \\
1.19 \\
2.20 \\
77.85\end{array}$ & $\begin{array}{c}35.56 \\
31.28 \\
27.02 \\
0.67 \\
2.79 \\
79.83\end{array}$ & $\begin{array}{c}7.08 \\
7.77 \\
5.99 \\
0.16 \\
2.95 \\
11.91\end{array}$ \\
\hline
\end{tabular}

concluded that the shorter and less branched sesame varieties (Shandaweel 3 and Toshka 1) were more pertinent for intercropping with groundnut. Similar results were obtained by Gabr (1999).

\section{Effect of sesame planting density}

Data in Table (3) showed that sesame planting density had a significant effect on all traits of groundnut in both seasons and their combined. With each increase in hill spacing and hence the decrease of sesame planting density there was a consistent significant increase in all growth and yield attributes of groundnut. Therefore the pod yield per plant and per fad. were progressively increased. It seemed that narrowing the distance between sesame plants to $20 \mathrm{~cm}$. diminished light penetration to groundnut plants and hence might have had decreased their photosynthesis which in turn, decrease the amount of photosynthates available for growth and development. The yield of groundnut when shaded with low sesame plant density $(50 \%)$ exceeded that with high dense sesame population (100\% plant density) by 31.66 , 27.51 and $29.53 \%$ in the first, the second and the combined data of the two seasons, respectively. These data are in agreement with obtained by Toaima et al (2004), Sherif Sahar et al (2005) and Abd El-Zaher et al (2007).

\section{Effect of the interaction}

The interaction effects of sesame varieties and sesame planting densities on growth, yield and yield components of groundnut were significant in some traits i.e. number of branches / plant in the first season and combined data, number of pods / plant in the second season and the combined data, seed index in the combined data and pod yield per plant and per fad. in both seasons and the combined data, (Table 4). It is evident from Table (4) that groundnut pod yield / fad. and its components 
Table 3. Effect of planting density sesame on yield and yield components of groundnut in the two seasons and their combined data

\begin{tabular}{|c|c|c|c|c|c|c|}
\hline Density & $\begin{array}{l}\text { Plant } \\
\text { height } \\
\text { (cm.) }\end{array}$ & $\begin{array}{c}\text { No. of } \\
\text { branches / } \\
\text { plant }\end{array}$ & $\begin{array}{l}\text { No. of } \\
\text { pods / } \\
\text { plant }\end{array}$ & $\begin{array}{c}\text { Seed } \\
\text { index } \\
(g)\end{array}$ & $\begin{array}{l}\text { Pod yield / } \\
\text { plant (g) }\end{array}$ & $\begin{array}{l}\text { Pod yield / } \\
\text { fad (ardab) }\end{array}$ \\
\hline \multicolumn{7}{|c|}{ First season } \\
\hline$S_{1}(100 \%)$ & 44.87 & 8.29 & 21.99 & 67.33 & 23.55 & 5.46 \\
\hline $\mathrm{S}_{2}(67 \%)$ & 48.02 & 9.02 & 25.24 & 69.78 & 29.00 & 6.54 \\
\hline $\mathrm{S}_{3}(50 \%)$ & 51.35 & 10.51 & 30.89 & 73.73 & 33.33 & 7.99 \\
\hline LSD & 3.41 & 0.59 & 1.24 & 3.73 & 1.61 & 0.29 \\
\hline C.V. & 6.92 & 6.17 & 4.62 & 5.17 & 5.46 & 4.30 \\
\hline Solid & 56.67 & 12.80 & 42.20 & 78.97 & 73.00 & 10.92 \\
\hline \multicolumn{7}{|c|}{ Second season } \\
\hline$S_{1}(100 \%)$ & 45.82 & 9.14 & 26.78 & 67.17 & 28.81 & 6.14 \\
\hline $\mathrm{S}_{2}(67 \%)$ & 48.15 & 10.02 & 31.84 & 69.91 & 33.45 & 7.09 \\
\hline $\mathrm{S}_{3}(50 \%)$ & 50.84 & 11.67 & 36.49 & 73.27 & 39.55 & 8.47 \\
\hline LSD & 2.81 & 0.50 & 0.80 & 4.24 & 1.11 & 0.20 \\
\hline C.V. & 6.34 & 4.77 & 3.01 & 5.89 & 3.17 & 2.93 \\
\hline Solid & 61.00 & 13.33 & 44.13 & 76.73 & 86.67 & 12.90 \\
\hline \multicolumn{7}{|c|}{ Combined data of the two seasons } \\
\hline$S_{1}(100 \%)$ & 45.35 & 8.71 & 24.39 & 67.25 & 26.18 & 5.80 \\
\hline $\mathrm{S}_{2}(67 \%)$ & 48.09 & 9.52 & 28.54 & 69.88 & 31.22 & 6.81 \\
\hline $\mathrm{S}_{3}(50 \%)$ & 51.10 & 11.09 & 33.69 & 73.67 & 36.44 & 8.23 \\
\hline LSD & 2.09 & 0.37 & 0.75 & 1.09 & 0.92 & 0.17 \\
\hline C.V. & 6.29 & 5.45 & 3.76 & 4.06 & 4.29 & 3.52 \\
\hline Solid & 58.83 & 13.00 & 43.16 & 77.85 & 79.83 & 11.91 \\
\hline
\end{tabular}

were significantly increased with the decrease of sesame planting density but with different magnitudes the increase of pod yield / fad. was more pronounced under Toshka 1 intercrop followed by shandeweel 3 which amounted to $52.3 \%$ in the former compared with $34.1 \%$ in the latter. This increase amounted to $39.1 \%$ under Giza 32. The differential response of groundnut pod yield / fad., which reflects the differential response of its yield components, clearly indicate that the three sesame varieties adversely affected the growth and yield of groundnut. This adverse effect varied with the variation of variety and its planting density. Generally, each decrease of sesame density was followed by a noticeable increase in groundnut pod yield / fad. However, Toshka 1 variety favoured the growth and hence pod yield / fad. of groundnut to a greater extent than Giza 32 where Shandaweel 3 variety had a moderate effect in this respect. The interaction between sesame varieties and their planting density followed the response of sesame seed yield / fad. to the increase of planting density (Table 4). It was mentioned that Giza 32 was the least responsive to the decrease of density $100 \%$ to $50 \%$ where it showed greater compensation for the decrease of planting density through more branching. Therefore this cultivar showed more aggressivity against groundnut, where the decrease of its plants population did not yield as much increase in the groundnut pod yield / fad. as that observed under Toshka 1 or Shandaweel 3. According to this interaction, groundnut was more benefited from the decrease to plant population of Toshka 1 than of Giza 32 where Shandaweel 3 had a moderate effect in this respect.

The relationship between pod yield of groundnut and the planting density of sesame varieties represented a linear relation as indicated by the following equations and as illustrated in Figure (1). 
Table 4. Effect of the interaction between sesame varieties and planting density on yield and yield components of groundnut in the two seasons and their combined data

\begin{tabular}{|c|c|c|c|c|c|c|c|}
\hline Varieties & Density & $\begin{array}{c}\text { Plant } \\
\text { height } \\
\text { (cm.) }\end{array}$ & $\begin{array}{c}\text { No. of } \\
\text { branches / } \\
\text { plant }\end{array}$ & $\begin{array}{c}\text { No. of } \\
\text { pods / } \\
\text { plant }\end{array}$ & $\begin{array}{c}\text { Seed } \\
\text { index } \\
(g)\end{array}$ & $\begin{array}{c}\text { Pod } \\
\text { yield / } \\
\text { plant (g) }\end{array}$ & $\begin{array}{c}\text { Pod yield } \\
\text { / fad (ar- } \\
\text { dab) }\end{array}$ \\
\hline \multicolumn{8}{|c|}{ First season } \\
\hline \multirow{3}{*}{$\mathbf{A}_{1}$ Shandaweel 3} & $S_{1}(100 \%)$ & 45.60 & 7.67 & 23.12 & 73.08 & 31.33 & 6.10 \\
\hline & $\mathrm{S}_{2}(67 \%)$ & 49.00 & 8.93 & 25.80 & 74.26 & 35.67 & 6.27 \\
\hline & $\mathrm{S}_{3}(50 \%)$ & 55.13 & 11.40 & 31.93 & 74.82 & 36.67 & 8.53 \\
\hline \multirow{3}{*}{$A_{2}$ Toshka 1} & $S_{1}(100 \%)$ & 42.80 & 9.80 & 23.13 & 65.57 & 24.33 & 5.41 \\
\hline & $\mathrm{S}_{2}(67 \%)$ & 48.80 & 10.40 & 25.00 & 69.65 & 29.67 & 7.64 \\
\hline & $\mathrm{S}_{3}(50 \%)$ & 51.60 & 10.67 & 31.80 & 70.90 & 31.33 & 8.83 \\
\hline \multirow{3}{*}{$A_{3}$ Giza 32} & $S_{1}(100 \%)$ & 46.20 & 7.40 & 19.73 & 63.33 & 15.00 & 4.87 \\
\hline & $\mathrm{S}_{2}(67 \%)$ & 46.27 & 7.73 & 24.93 & 65.43 & 21.67 & 5.70 \\
\hline & $\mathrm{S}_{3}(50 \%)$ & 47.33 & 9.47 & 28.93 & 75.48 & 32.00 & 6.60 \\
\hline \multicolumn{2}{|l|}{ LSD } & NS & 1.02 & NS & NS & 2.78 & 0.51 \\
\hline \multicolumn{2}{|l|}{ C.V. } & - & 6.17 & 4.62 & - & 5.46 & 4.30 \\
\hline \multicolumn{2}{|l|}{ Solid } & 56.67 & 12.80 & 42.20 & 78.97 & 73.00 & 10.92 \\
\hline \multicolumn{8}{|c|}{ Second season } \\
\hline \multirow{3}{*}{ A $_{1}$ Shandaweel 3} & $S_{1}(100 \%)$ & 47.33 & 8.47 & 25.80 & 73.54 & 32.00 & 6.38 \\
\hline & $\mathrm{S}_{2}(67 \%)$ & 49.73 & 10.27 & 31.07 & 73.75 & 33.67 & 6.98 \\
\hline & $\mathrm{S}_{3}(50 \%)$ & 51.20 & 11.80 & 40.27 & 74.18 & 44.00 & 8.22 \\
\hline \multirow{3}{*}{$A_{2}$ Toshka 1} & $S_{1}(100 \%)$ & 46.93 & 11.47 & 27.67 & 63.64 & 28.33 & 6.92 \\
\hline & $\mathrm{S}_{2}(67 \%)$ & 49.93 & 11.00 & 32.53 & 69.64 & 34.67 & 7.92 \\
\hline & $\mathrm{S}_{3}(50 \%)$ & 51.33 & 12.20 & 35.60 & 72.32 & 39.33 & 9.92 \\
\hline \multirow{3}{*}{$A_{3}$ Giza 32} & $S_{1}(100 \%)$ & 43.20 & 8.47 & 26.87 & 64.33 & 26.10 & 5.11 \\
\hline & $\mathrm{S}_{2}(67 \%)$ & 44.80 & 8.80 & 31.93 & 66.34 & 32.00 & 6.37 \\
\hline & $\mathrm{S}_{3}(50 \%)$ & 50.00 & 11.00 & 33.60 & 73.31 & 35.33 & 7.28 \\
\hline \multicolumn{2}{|l|}{ LSD } & NS & NS & 1.70 & NS & 1.92 & 0.35 \\
\hline \multicolumn{2}{|l|}{ C.V. } & - & 4.77 & 3.01 & - & 3.17 & 2.93 \\
\hline \multicolumn{2}{|l|}{ Solid } & 61.00 & 13.33 & 44.13 & 76.73 & 86.67 & 12.90 \\
\hline \multicolumn{8}{|c|}{ Combined data of the two seasons } \\
\hline \multirow{3}{*}{$A_{1}$ Shandaweel 3} & $S_{1}(100 \%)$ & 46.47 & 8.12 & 24.46 & 73.31 & 31.67 & 6.24 \\
\hline & $\mathrm{S}_{2}(67 \%)$ & 49.37 & 9.60 & 28.43 & 74.01 & 34.67 & 6.63 \\
\hline & $\mathrm{S}_{3}(50 \%)$ & 53.17 & 11.60 & 36.10 & 74.50 & 40.33 & 8.37 \\
\hline \multirow{3}{*}{$\mathrm{A}_{2}$ Toshka 1} & $S_{1}(100 \%)$ & 44.87 & 10.13 & 25.40 & 64.61 & 26.33 & 6.16 \\
\hline & $\mathrm{S}_{2}(67 \%)$ & 49.37 & 10.70 & 28.77 & 69.65 & 32.17 & 7.78 \\
\hline & $\mathrm{S}_{3}(50 \%)$ & 51.47 & 11.44 & 33.70 & 71.61 & 35.33 & 9.38 \\
\hline \multirow{3}{*}{$A_{3}$ Giza 32} & $S_{1}(100 \%)$ & 44.70 & 7.94 & 23.30 & 63.83 & 20.55 & 4.99 \\
\hline & $\mathrm{S}_{2}(67 \%)$ & 45.53 & 8.27 & 28.43 & 65.89 & 26.83 & 6.04 \\
\hline & $S_{3}(50 \%)$ & 48.67 & 10.24 & 31.27 & 74.90 & 33.67 & 6.94 \\
\hline \multicolumn{2}{|l|}{ LSD } & NS & 0.64 & 1.29 & 3.40 & 1.66 & 0.29 \\
\hline \multicolumn{2}{|l|}{ C.V. } & - & 5.45 & 3.76 & 4.06 & 4.29 & 3.52 \\
\hline \multicolumn{2}{|l|}{ Solid } & 58.83 & 13.00 & 43.16 & 77.85 & 79.83 & 11.91 \\
\hline
\end{tabular}


Figure (1)

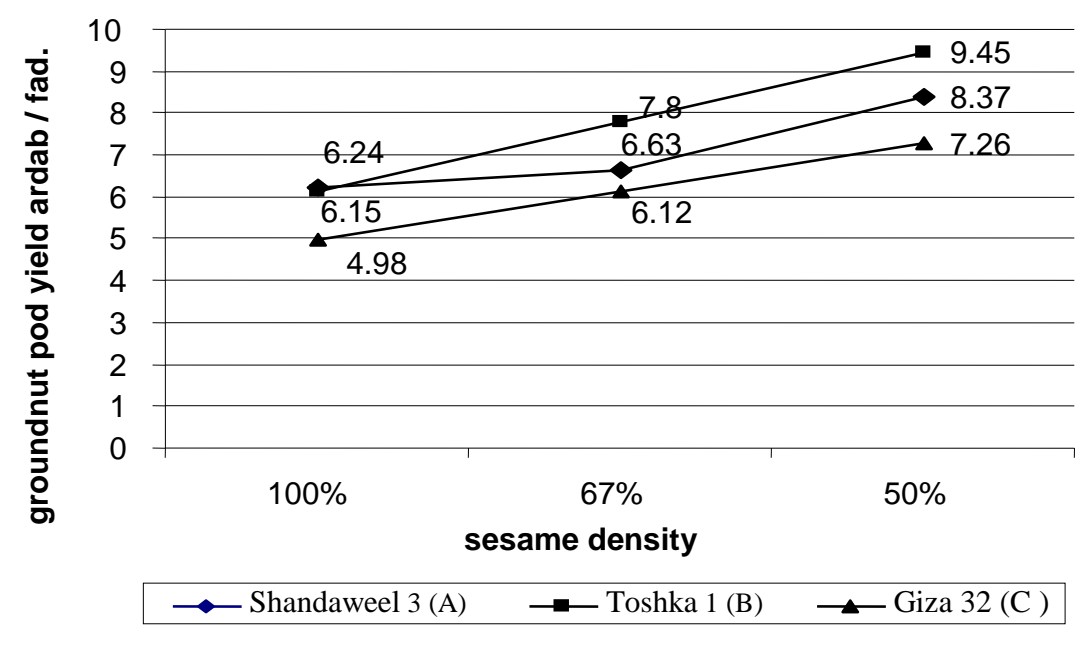

Figure 1. Relation between the pod yield of groundnut and planting density of sesame

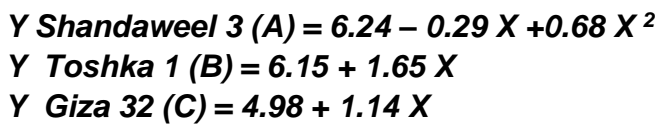

Where: $\mathrm{X}=$ estimated $100 \%=$ zero, $67 \%=1$ and $50 \%=2$ planting density of sesame.

It is evident that the response equations of pod yield / fad. of groundnut was linear with each decrease of sesame planting density and with higher magnitude under Toshka 1 than under the other to sesame varieties.

\section{II- Sesame}

\section{Varietal differences}

Data in Table (5) showed significant differences in all traits except seed index in both seasons and the combined data of the two seasons. Data indicated that growth traits yield and yield component of the three sesame varieties were decreased under intercropping conditions in both seasons and the combined of the two seasons. The reduction in Shandaweel 3, Toshka 1 and Giza 32 varieties were 9.04, 2.71 and $9.04 \%$ for plant height $6.94,3.69$ and $7.73 \%$ for number of branches / plant 0.63, 7.04 and $14.93 \%$ for number of capsules / plant 2.77, 1.88 and $7.36 \%$ for seed index $9.61,5.30$ and $1.87 \%$ for seed yield / plant and $34.74,27.54$ and $15.48 \%$ for seed yield / fad of their solids in the combined data of the two seasons. Giza 32 variety surpassed the other verities (Shandaweel 3 and Toshka 1) in plant height, number of branches and capsules / plant, seed yield / plant and seed yield / fad, while Toshka 1 had the highest value of seed index only. These results hold fairly true in the second season and the combined data of the two seasons. The lowest values of those traits were observed with Shandaweel 3 variety with few exceptions (Table 5). Differences between the three sesame varieties may be attributed to their genetic differences and interaction between the genetically make-up and the environmental conditions. Similar conclusion was reported by El-Serogy et al (1997) and Rahnama and Bakhshandeh (2006).

\section{Effect of planting density}

Data in Table (6) revealed that sesame density had significant effect on all traits except seed index in both seasons. The highest values of sesame plants reached its maximum when sesame was planted at $50 \%$ density, whereas at $100 \%$ density recorded minimum values. The same trend could be detected for the average number of branches / plant. These results were true in both seasons and the combined data. Yield components of sesame i.e number of capsules / plant, seed index and seed yield / plant were superior when planted at $50 \%$ density followed by those planted at $67 \%$ density. It is clear that yield component traits were increased consistently and regularly with increasing sesame density. The highest plant density (100\%) recorded the highest seed yield / fad and 
Table 5. Effect of sesame varieties on yield and yield components in the two seasons and their combined data

\begin{tabular}{|c|c|c|c|c|c|c|}
\hline Varieties & $\begin{array}{c}\text { Plant } \\
\text { height } \\
(\mathbf{c m})\end{array}$ & $\begin{array}{c}\text { No. of } \\
\text { branches / } \\
\text { plant }\end{array}$ & $\begin{array}{c}\text { No. of } \\
\text { capsules / } \\
\text { plant }\end{array}$ & $\begin{array}{l}\text { Seed } \\
\text { index } \\
(g)\end{array}$ & $\begin{array}{c}\text { Seed } \\
\text { yield / } \\
\text { plant (g) }\end{array}$ & $\begin{array}{l}\text { Seed yield / } \\
\text { fad (ardab) }\end{array}$ \\
\hline \multicolumn{7}{|c|}{ First season } \\
\hline$A_{1}$ Shandaweel 3 & 98.00 & 1.96 & 108.44 & 4.49 & 11.91 & 3.34 \\
\hline$A_{2}$ Toshka 1 & 103.09 & 2.05 & 106.42 & 4.64 & 12.11 & 3.87 \\
\hline$A_{3}$ Giza 32 & 123.46 & 4.13 & 135.55 & 4.47 & 14.75 & 4.42 \\
\hline LSD & 3.42 & 0.093 & 6.58 & NS & 0.29 & 0.14 \\
\hline C.V. & 2.42 & 2.61 & 4.30 & 2.79 & 1.71 & 2.71 \\
\hline Solid $A_{1}$ & 104.00 & 1.5 & 109.80 & 4.60 & 12.87 & 5.72 \\
\hline Solid $A_{2}$ & 104.00 & 1.6 & 114.40 & 4.63 & 12.13 & 5.80 \\
\hline Solid $A_{3}$ & 134.33 & 2.33 & 171.20 & 4.90 & 15.13 & 5.70 \\
\hline \multicolumn{7}{|c|}{ Second season } \\
\hline$A_{1}$ Shandaweel 3 & 98.84 & 2.05 & 108.87 & 4.62 & 15.22 & 3.75 \\
\hline$A_{2}$ Toshka 1 & 100.91 & 2.15 & 109.07 & 4.77 & 16.11 & 4.39 \\
\hline$A_{3}$ Giza 32 & 123.96 & 4.22 & 163.74 & 4.60 & 16.78 & 5.30 \\
\hline LSD & 3.56 & 0.10 & 2.90 & NS & 0.399 & 0.25 \\
\hline C.V. & 2.52 & 2.76 & 1.74 & 3.12 & 1.90 & 4.24 \\
\hline Solid $\mathbf{A}_{1}$ & 112.33 & 1.7 & 108.93 & 4.77 & 16.67 & 5.16 \\
\hline Solid $A_{2}$ & 105.67 & 1.8 & 117.40 & 4.97 & 16.67 & 5.60 \\
\hline Solid $A_{3}$ & 138.67 & 2.73 & 180.60 & 4.87 & 17.00 & 5.80 \\
\hline \multicolumn{7}{|c|}{ Combined data of the two seasons } \\
\hline$A_{1}$ Shandaweel 3 & 98.42 & 2.01 & 108.68 & 4.56 & 13.35 & 3.55 \\
\hline$A_{2}$ Toshka 1 & 102.00 & 2.09 & 107.74 & 4.71 & 14.11 & 4.13 \\
\hline$A_{3}$ Giza 32 & 123.71 & 4.18 & 149.64 & 4.53 & 15.77 & 4.86 \\
\hline LSD & 2.05 & 0.002 & 2.99 & 0.103 & 0.18 & 0.12 \\
\hline C.V. & 2.46 & 2.86 & 3.18 & 2.92 & 1.64 & 3.63 \\
\hline Solid $A_{1}$ & 108.20 & 1.6 & 109.37 & 4.69 & 14.77 & 5.44 \\
\hline Solid $A_{2}$ & 104.84 & 1.7 & 115.90 & 4.80 & 14.90 & 5.70 \\
\hline Solid $\mathbf{A}_{3}$ & 136.00 & 2.53 & 175.90 & 4.89 & 16.07 & 5.75 \\
\hline
\end{tabular}

was significantly superior to those of medium and low plant densities in both seasons and the combined data of the two seasons. The seed yield / fad of high plant density was 46.93 and $13.50 \%$ in the first season, 2.46 and $8.71 \%$ in the second season and 25.86 and $11.19 \%$ in the combined data over low and medium plant densities, respectively. These results revealed that under low plants density the increases in number of branches and capsules / plant, seed index and seed yield / plant, could not compensate the yield loss because of less population and vice versa under high density. These results are in agreement with those obtained by El-Serogy et al (1997), Ghungarde et al (1992), Chimanshette and Dhoble (1992), Ghosh and Patra (1994) and Rahnama and Bakhshandeh (2006).

\section{Effect of the interaction}

The interaction effects of sesame varieties and plant density on growth, yield and yield components were significant in all trait of sesame except 
Table 6. Effect of sesame density on yield and yield components of sesame in the two seasons and their combined data

\begin{tabular}{|c|c|c|c|c|c|c|}
\hline Density & $\begin{array}{c}\text { Plant } \\
\text { height } \\
\text { (cm.) }\end{array}$ & $\begin{array}{c}\text { No. of } \\
\text { branches / } \\
\text { plant }\end{array}$ & $\begin{array}{c}\text { No. of } \\
\text { capsules / } \\
\text { plant }\end{array}$ & $\begin{array}{c}\text { Seed index } \\
\text { (g) }\end{array}$ & $\begin{array}{l}\text { Seed yield } \\
\text { / plant (g) }\end{array}$ & $\begin{array}{l}\text { Seed yield / } \\
\text { fad (ardab) }\end{array}$ \\
\hline \multicolumn{7}{|c|}{ First season } \\
\hline$S_{1}(100 \%)$ & 96.76 & 1.86 & 105.36 & 4.31 & 11.29 & 4.54 \\
\hline $\mathrm{S}_{2}(67 \%)$ & 106.80 & 2.88 & 120.84 & 4.55 & 12.60 & 4.00 \\
\hline $\mathrm{S}_{3}(50 \%)$ & 120.75 & 3.40 & 124.22 & 4.73 & 14.89 & 3.09 \\
\hline LSD & 5.31 & 0.065 & 8.18 & NS & 0.444 & 0.16 \\
\hline C.V. & 4.78 & 2.33 & 6.81 & 8.86 & 3.34 & 4.00 \\
\hline Solid $A_{1}$ & 104.00 & 1.5 & 109.80 & 4.2 & 12.87 & 5.72 \\
\hline Solid $A_{2}$ & 104.00 & 1.6 & 94.4 & 4.63 & 12.13 & 5.80 \\
\hline Solid $A_{3}$ & 134.33 & 2.33 & 171.2 & 4.90 & 15.13 & 5.70 \\
\hline \multicolumn{7}{|c|}{ Second season } \\
\hline$S_{1}(100 \%)$ & 96.91 & 1.97 & 123.16 & 4.50 & 14.11 & 4.99 \\
\hline $\mathrm{S}_{2}(67 \%)$ & 107.02 & 2.97 & 126.38 & 4.68 & 15.78 & 4.59 \\
\hline $\mathrm{S}_{3}(50 \%)$ & 119.78 & 3.49 & 132.13 & 4.81 & 18.22 & 4.87 \\
\hline LSD & 6.51 & 0.056 & 5.48 & NS & 4.84 & 0.23 \\
\hline C.V. & 5.88 & 1.95 & 4.20 & 7.29 & 2.94 & 5.04 \\
\hline Solid $A_{1}$ & 112.33 & 1.7 & 108.73 & 4.47 & 16.67 & 5.16 \\
\hline Solid $\mathbf{A}_{2}$ & 105.67 & 1.8 & 97.4 & 4.97 & 16.67 & 5.60 \\
\hline Solid $\mathbf{A}_{3}$ & 138.67 & 2.73 & 180.6 & 4.87 & 17.00 & 5.80 \\
\hline \multicolumn{7}{|c|}{ Combined data of the two seasons } \\
\hline $\mathrm{S}_{1}(100 \%)$ & 96.84 & 1.91 & 114.26 & 4.41 & 12.70 & 4.77 \\
\hline $\mathrm{S}_{2}(67 \%)$ & 106.24 & 2.92 & 123.63 & 4.62 & 14.19 & 4.29 \\
\hline $\mathrm{S}_{3}(50 \%)$ & 120.39 & 3.44 & 128.18 & 4.77 & 16.33 & 3.79 \\
\hline LSD & 3.98 & 0.038 & 4.66 & 0.26 & 0.31 & 0.13 \\
\hline C.V. & 5.35 & 1.98 & 5.55 & 8.08 & 3.15 & 4.66 \\
\hline Solid $A_{1}$ & 108.20 & 1.6 & 109.27 & 4.34 & 14.77 & 5.44 \\
\hline Solid $A_{2}$ & 104.84 & 1.7 & 95.9 & 4.80 & 14.90 & 5.70 \\
\hline Solid $A_{3}$ & 136.00 & 2.53 & 175.9 & 4.89 & 16.07 & 5.75 \\
\hline
\end{tabular}

number of capsules / plant in the second season and seed index in the both seasons and the combined data (Table 7). Plant height of sesame reached maximum values in Giza 32 variety when planted at $50 \%$ density, whereas the minimum values were observed with Shandaweel 3 and $100 \%$ plant density. Same trend could be detected for average number of branches, capsules / plant and seed yield / plant as influenced by plants density. The maximum values of seed index were recorded by Toshka 1 when planted at $50 \%$ density, while the lowest value by Shandaweel 3 when planted at $100 \%$ density in both seasons and the combined data. Maximum value of seed yield / fad was recorded by Giza 32 variety when planted at $100 \%$ density, whereas the minimum values was recorded by Shandaweel 3 in the first season and
Toshka 1 in the second season when planted at $50 \%$ density. Doubling the planting density decreased plant height and branching in the three varieties but with different magnitudes. Giza 32 was the most sensitive regarding plant height, but the least sensitive regarding branching. This varietals response was judged through the percentage decrease in height and branching averages due to doubling the planting density. Regarding seed yield / fad. Giza 32 was the least responsive the planting density whereas Toshka 1 most responsive. The percentage increase in seed yield / fad. amounted to $15.2 \%$ and $68.9 \%$ respectively.

The relationship between seed yield of sesame varieties and planting density is represented by the following equation for each sesame variety in Figure (2). 
Table 7. Effect of interaction between sesame varieties and planting density on yield and yield components of sesame in the two seasons and their combined data

\begin{tabular}{|c|c|c|c|c|c|c|c|}
\hline Varieties & Density & $\begin{array}{l}\text { Plant } \\
\text { height } \\
\text { (cm.) }\end{array}$ & $\begin{array}{c}\text { No. of } \\
\text { branches / } \\
\text { plant }\end{array}$ & $\begin{array}{l}\text { No. of } \\
\text { capsules } \\
\text { / plant }\end{array}$ & $\begin{array}{c}\text { Seed } \\
\text { index } \\
(g)\end{array}$ & $\begin{array}{l}\text { Seed yield } \\
\text { / plant }(\mathrm{g})\end{array}$ & $\begin{array}{c}\text { Seed } \\
\text { yield / } \\
\text { fad } \\
\text { (ardab) }\end{array}$ \\
\hline \multicolumn{8}{|c|}{ First season } \\
\hline \multirow{3}{*}{$A_{1}$ Shandaweel 3} & $S_{1}(100 \%)$ & 90.67 & 1.20 & 105.47 & 4.20 & 10.20 & 3.75 \\
\hline & $\mathrm{S}_{2}(67 \%)$ & 95.40 & 2.17 & 106.73 & 4.53 & 11.87 & 3.65 \\
\hline & $\mathrm{S}_{3}(50 \%)$ & 107.93 & 2.50 & 113.13 & 4.73 & 13.67 & 2.62 \\
\hline \multirow{3}{*}{$A_{2}$ Toshka 1} & $S_{1}(100 \%)$ & 94.93 & 1.27 & 104.87 & 4.40 & 11.67 & 4.88 \\
\hline & $\mathrm{S}_{2}(67 \%)$ & 105.00 & 2.27 & 106.87 & 4.73 & 12.00 & 4.13 \\
\hline & $\mathrm{S}_{3}(50 \%)$ & 109.33 & 2.60 & 107.53 & 4.80 & 12.67 & 2.59 \\
\hline \multirow{3}{*}{$A_{3}$ Giza 32} & $S_{1}(100 \%)$ & 104.67 & 3.10 & 105.73 & 4.33 & 12.00 & 4.99 \\
\hline & $\mathrm{S}_{2}(67 \%)$ & 120.0 & 4.20 & 148.93 & 4.40 & 13.93 & 4.21 \\
\hline & $\mathrm{S}_{3}(50 \%)$ & 145.73 & 5.10 & 152.00 & 4.67 & 18.33 & 4.05 \\
\hline & 9.20 & 0.113 & 14.17 & NS & 0.769 & 0.28 \\
\hline \multirow{2}{*}{\multicolumn{2}{|c|}{$\begin{array}{l}\text { C.V. } \\
\text { Solid A1 }\end{array}$}} & 4.78 & 2.33 & 6.18 & 8.86 & 3.34 & 4.00 \\
\hline & & 104.00 & 1.5 & 109.80 & 4.2 & 12.87 & 5.72 \\
\hline \multirow{2}{*}{\multicolumn{2}{|c|}{$\begin{array}{ll}\text { Solid } & A_{2} \\
\text { Solid } & A_{3}\end{array}$}} & 104.00 & 1.6 & 94.4 & 4.63 & 12.13 & 5.80 \\
\hline & & 134.33 & 2.33 & 171.2 & 4.90 & 15.13 & 5.70 \\
\hline \multicolumn{8}{|c|}{ Second season } \\
\hline \multirow{3}{*}{$A_{1}$ Shandaweel 3} & $S_{1}(100 \%)$ & 94.00 & 1.30 & 105.00 & 4.37 & 12.67 & 4.28 \\
\hline & $\mathrm{S}_{2}(67 \%)$ & 97.53 & 2.27 & 107.47 & 4.63 & 15.67 & 3.75 \\
\hline & $\mathrm{S}_{3}(50 \%)$ & 105.00 & 2.60 & 114.13 & 4.87 & 17.33 & 3.21 \\
\hline \multirow{3}{*}{$A_{2}$ Toshka 1} & $S_{1}(100 \%)$ & 90.07 & 1.40 & 106.80 & 4.60 & 15.00 & 5.21 \\
\hline & $\mathrm{S}_{2}(67 \%)$ & 105.67 & 2.37 & 109.00 & 4.80 & 16.00 & 4.59 \\
\hline & $\mathrm{S}_{3}(50 \%)$ & 107.00 & 2.67 & 111.40 & 4.90 & 17.33 & 3.38 \\
\hline \multirow{3}{*}{$A_{3}$ Giza 32} & $S_{1}(100 \%)$ & 106.67 & 3.20 & 157.67 & 4.53 & 14.67 & 5.47 \\
\hline & $\mathrm{S}_{2}(67 \%)$ & 117.87 & 4.27 & 162.67 & 4.60 & 15.67 & 5.42 \\
\hline & $\mathrm{S}_{3}(50 \%)$ & 147.33 & 5.20 & 170.87 & 4.67 & 20.00 & 5.02 \\
\hline \multirow{3}{*}{\multicolumn{2}{|c|}{$\begin{array}{l}\text { LSD } \\
\text { C.V. } \\
\text { Solid } A_{1}\end{array}$}} & 11.28 & 0.097 & NS & NS & 0.838 & 0.402 \\
\hline & & 5.88 & 1.95 & 4.20 & 7.29 & 2.94 & 5.04 \\
\hline & & 112.33 & 1.7 & 108.73 & 4.47 & 16.67 & 5.16 \\
\hline \multicolumn{2}{|c|}{$\begin{array}{l}\text { Solid } A_{1} \\
\text { Solid } A_{2}\end{array}$} & 105.67 & 1.8 & 97.4 & 4.97 & 16.67 & 5.60 \\
\hline \multicolumn{2}{|c|}{ Solid $A_{3}$} & 138.67 & 2.73 & 180.6 & 4.87 & 17.00 & 5.80 \\
\hline \multicolumn{8}{|c|}{ Combined data of the two seasons } \\
\hline \multirow{3}{*}{$A_{1}$ Shandaweel 3} & $S_{1}(100 \%)$ & 92.34 & 1.25 & 105.24 & 4.28 & 11.44 & 4.02 \\
\hline & $\mathrm{S}_{2}(67 \%)$ & 94.47 & 2.22 & 107.17 & 4.58 & 13.77 & 3.70 \\
\hline & $\mathrm{S}_{3}(50 \%)$ & 106.47 & 2.55 & 113.63 & 4.80 & 14.83 & 2.92 \\
\hline \multirow{3}{*}{$\mathrm{A}_{2}$ Toshka 1} & $S_{1}(100 \%)$ & 92.50 & 1.33 & 105.84 & 4.50 & 13.33 & 5.05 \\
\hline & $\mathrm{S}_{2}(67 \%)$ & 105.33 & 2.32 & 107.93 & 4.77 & 14.00 & 4.36 \\
\hline & $\mathrm{S}_{3}(50 \%)$ & 108.17 & 2.63 & 109.47 & 4.85 & 15.00 & 2.99 \\
\hline \multirow{3}{*}{$A_{3}$ Giza 32} & $S_{1}(100 \%)$ & 105.67 & 3.15 & 131.70 & 4.43 & 13.33 & 5.23 \\
\hline & $\mathrm{S}_{2}(67 \%)$ & 118.93 & 4.23 & 155.80 & 4.50 & 14.80 & 4.32 \\
\hline & $\mathrm{S}_{3}(50 \%)$ & 146.53 & 5.15 & 161.44 & 4.67 & 19.17 & 4.54 \\
\hline \multirow{2}{*}{\multicolumn{2}{|c|}{$\begin{array}{l}\text { LSD } \\
\text { C.V. }\end{array}$}} & 6.90 & 0.065 & 8.08 & NS & 0.54 & 0.23 \\
\hline & & 5.35 & 1.98 & 5.55 & 8.08 & 3.15 & 4.66 \\
\hline \multicolumn{2}{|c|}{ Solid $A_{1}$} & 108.20 & 1.6 & 109.27 & 4.34 & 14.77 & 5.44 \\
\hline \multicolumn{2}{|c|}{ Solid $A_{2}$} & 104.84 & 1.7 & 95.9 & 4.80 & 14.90 & 5.70 \\
\hline \multicolumn{2}{|c|}{ Solid $\mathbf{A}_{3}$} & 136.00 & 2.53 & 175.9 & 4.89 & 16.07 & 5.75 \\
\hline
\end{tabular}


Figure (2)

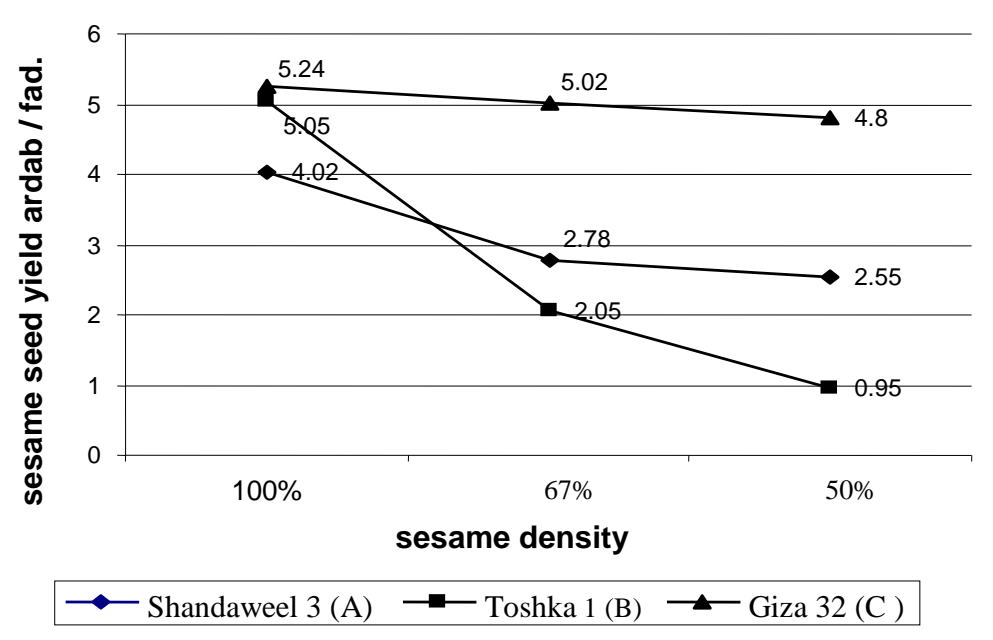

Figure 2 . Relation between seed yield of sesame and planting density

The relation between seed yield of sesame varieties and planting density which follows the equation.

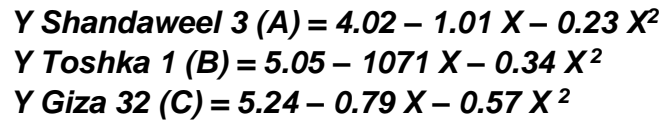

Where: $X=$ estimated $100 \%=$ Zero, $67 \%=1$ and $50 \%=2$ planting density.

According to the response of sesame seed yield varieties/fad. to the decrease to planting density from $100 \%$ to $50 \%$, Toshka 1 was the most responsive, whereas, Giza 32 was the least responsive. This response amounted to $2.15 \mathrm{ardab} /$ fad. for Toshka 1 compared with only 0.27 ardab / fad. for Giza 32. However Shandaweel 3 showed a moderate response which amounted to 1.11 ardab / fad.

This differential response, clearly indicates that Giza 32 with its high branches capsules, (2.53 branch / plant ) could compensate for the decrease of plant population, whereas, Toshka 1 followed by Shandaweel 3 varieties, (1.7 and $1.6 /$ plant, respectively) could not as mach compensate for the decrease of population and hence were more responsive to the decrease to planting density.

\section{III- Competitive relationships and yield ad- vantages}

\section{Land Equivalent Ratio (LER)}

Data in Table (8) indicated that land equivalent ratio LER showed considerable yield advantage resulting from intercropping groundnut with the three sesame varieties in the combined data of the two seasons. The results also revealed that intercropped groundnut with sesame varieties resulted in decreased yield of either crops. The results cleared that yields advantage of sesame and groundnut was affected by sesame varieties and planting density of sesame. The highest value of RYS (0.91) was recorded by Giza32 and the high sesame plant density whereas the lowest values (0.52) was recorded by Toshka 1 and the low plant density. While the highest value of $R Y_{G}(0.79)$ was recorded by intercropping with Toshka 1 and low plant density and the lowest values $(0.42)$ were observed when intercropping with Giza 32 and high plant density.

Land equivalent ratio (LER) values were greater than one. It could be concluded that the actual productivity was higher than the expected productivity when groundnut was intercropped with different the sesame varieties and planting densities. The highest LER values (1.41) was observed due to intercropping groundnut with Toshka $1 \mathrm{cv}$ 
and with the high or medium planting density $(100 \%$ and $67 \%)$, while the lowest values (1.24) was observed by cv Shandaweel 3 and low plant density. These results are in agreement with those obtained by Toaima et al (2004) and El-Sawy et al (2006).

\section{Aggressivity (Ag)}

Data on the aggressivity revealed that values of Ag for sesame were positive, whereas it was negative for groundnut. It means that sesame was the dominant and the groundnut was the dominated. Aggressivity values were increased with each decreased of sesame planting density (Table 8). Similar results were observed by Gabr (1999) and Toaima et al (2004).

\section{Competitive ratio}

Data on the competitive ratio to estimate the exact degree of competition indicate that sesame was more competition than groundnut under intercropping condition indicating the dominance of sesame whereas groundnut was dominated (Table 8). The results showed that degree of competition was affected by sesame density. Competition ratio of sesame was higher in the medium planting density $(67 \%)$ and was reduced with low and high plant density. While competition ratio of groundnut was lowest when was intercropped with medium planting density of sesame and was increased in low and high density for Shandaweel 3 and Toshka 1 only.

\section{Actual yield loss (AYL)}

Similar trend to that of LER, Ag and CR was also observed for AYL (Table 8). In particular, AYL for the three sesame varieties was positive when intercropped with groundnut, which indicates a yield advantage for sesame, probably because of the positive effect of groundnut on sesame when grown in association while AYLG was negative, which indicates a yield disadvantage to groundnut. Also, AYLs under low and medium plant density were positive, which indicates yield advantage for sesame under low and medium plant density. While AYLg under plant density were positive with low plant density only which indicated yield advantage for groundnut under low sesame density. The partial AYL of sesame was greater than the partial AYL of groundnut, it was due to sesame crop was the dominant and groundnut was domi- nated crop. Quantification of yield loss or gain due to association with different varieties and plant density could not be obtained through partial LER since partial AYL shows the yield loss or gain by its sign and as well as its value. Thus there was AYL for sesame ranged from -0.096 to 0.261 when using high plant density, indicating a yield loss from 9.6 to $-26.1 \%$ compared with its sole crop. While AYL for groundnut ranged from -0.126 to -0.419 when intercropping with Giza 32 and indicating a yield loss of -12.6 to $-41.9 \%$. Whereas, AYL for groundnut in low and medium density of Shandaweel 3 and Toshka 1 ranged from +0.010 to +0.181 to indicating increase in yield by +1.0 to $+18.1 \%$ compared with its sole crop. Total AYL, also was positive when intercropping groundnut with low or medium sesame planting density, which indicates that this system was successful. Thus, there was a gain of $88.4 \%$ in medium density and $80.1 \%$ in low density increase in yield of system.

\section{Intercropping advantage (IA)}

The IA, which is an indicator of the economic feasibility of intercropping systems, indicated that some advantages systems were positive when using low or medium sesame planting density, which indicates that these intercropping systems had the highest economic advantage, whereas system of groundnut with high planting density of the three sesame varieties for Shandaweel 3 and Toahka 1 and with Giza 32, which had negative values, showed an economic disadvantage (Table 8). IA values of the three sesame varieties were positive, indication a yield advantage for sesame while IA for groundnut were negative, indicating a yield disadvantage for groundnut. IA total value was positive under medium and low densities which indicate that these intercropping systems had the highest economic advantage.

\section{Monetary advantage index (MAl)}

Similar trend to that of IA was observed for monetary advantage index (MAI). These values were positive when intercropping groundnut with the three sesame varieties under the three plant densities (Table 8). The highest MAI value (1666.85) was observed when groundnut was intercropped the medium planting density of Toshka 1 fallowed by Giza 32 (1374.77). The lowest value (909.86) was observed when it was intercropped under the low plant density of Shandaweel 3 . These results clear that using Toshka 1 had the highest values of MAI (1598.75). Whereas Shandaweel 3 recorded the low values (909.86). The 
results also showed that the medium plant density of sesame recorded the high value MAI (1396.973) which was reduced with the high and the low planting density. These findings are in agreement with the results of LER, Ag, CR and AYL. Similarly, Ghosh (2004).

\section{REFERENCES}

Abd El-Zaher, Sh.R. Mohamed, Wafaa. Kh. and S.E.A. Toaima (2007). Intercropping maize with peanut under two plant distribution and three planting dates. Annals Agric. Sci. Moshtohor 45(2): 545-560.

Abdul-Galil, A.A.; O.E. Zeiton; A.Y. EL-Bana and S.A. Mwafy (2000 b). Effect of row spacing and splitting of nitrogen on wheat under sandy soil conditions. II.Grain yield and inter - intra row competition. Proc. $9^{\text {th }}$ Conf Agron., Minufiya Univ., Egypt, pp. 71-91.

Badran, M.S. (2002). Solid versus intercropping sesame with groundnut at different sequences of sowing dates. III. competitive relations. Alex. J. Agric. Res. 47(3): 31-39

Banik P. Banik. (1996). Evalution of wheat (Triticum aestivum) and legume intercropping under 1:1 and 2:1 row replacement series system, J.Agron Crop Sci. 176: 289-294.

Banik P. Banik.; T. Sasmal, P.K. Ghosal and D.K. Bagchi, (2000). Evaluation of mustard (Brassica compestris var. Toria) and legume intercropping under $1: 1$ and 2:1 row-replacement series system, J. Agron. Crop Sci. 185: 9-14.

Bhatti, I.H.; R. Ahmad.; J. Abdul.; M.S. Nazir and T. Mahmood (2006). Competitive behavior of component crops in different sesame- legume intercropping systems. Int. J. Agric. \& Biol. 8(2): 165-167.

Channabasavanna, A.S. and R.A. Setty (1992). Response of sesame (Sesamum indicum L.) genotypes to plant densities under summer conditions. Indian J. Agron. 37(3): 601-602.

Chimanshette, T.G. and M.V. Dhoble (1992). Effect sowing date and plant density on seed yield of sesame (Sesamum indicum $L$ ) varieties. Indian. J. Agron. 37(2): 280-282.

Delgado, M. and D.M. Yamonos. (1975). Yield component of sesame (Sesamum indicum L.) under different populations. Econ. Bot. 29(1): 68-78. Dhoble, M.T.; T.G. Chimanshette and V.D. Sondge (1993). Appraisal of yield- plant density relation in rainy - season sesame (Sesamum indicum L.) on vartisols. Indian J. Agric. Sci. 63(3): 157-159.
El-Mihi, M.A.; A.S. El-Gamel; M.A.. El-Masry and A.S. Kamel (1990). Growth and yield of sesame and groundnut in monoculture and association under different patterns and plant spacing. Proc. $4^{\text {th }}$ Conf. Agron., Cairo, 15-16 Sept., 11: 571-580.

El-Sawy, W.A.; M.G.M. El-Baz and S.E.A.Toaima (2006). Response of two peanut varieties to intercropping with sunflower under different sunflower sowing dates. Egypt. J. Appl. Sci, 21(3): 193-210. El-Serogy, S.T.; M.A. El-Emam and W.A.L. Sorour (1997). The performance of two sesame varieties under different sowing methods in two locations- Annals Agric. Sci.; Ain Shams, Univ. Cairo, 42(2): 335- 364.

Gabr, E.M.A. (1999). Effect of preceding winter crops and intercropping patterns on maize and peanut in newly reclaimed soils. J. Agric. Sci. Mansoura Univ., 24(11): 6333-6347.

Ghosh, D.C. and A.K. Patra (1994). Effect of plant density and fertility levels on productivity and economics of summer sesame (Sesame indium). Indian J. Agron. 39(1): 71-75.

Ghosh, P.K. (2004). Growth yield, competition and economics of groundnut / cereal fodder intercropping systems in the semi-arid tropics of India. Field Crops Res. 88: 227-237.

Ghungarde, S.R.; D.A. Charan; U.N. Alse.; G.V. Yeagaonkar and V.N. Pangarkar. (1992). Effect of plant density and variety on yield of sesame (Sesamum indicum). Indian J. Agron. 37(2): 385386.

Mc-Gilichrist, C.A. (1960). Analysis and competition experiments. Biometrics, 21: 975-985.

MSTAT (1986). A Microcomputer-Program of the Design Management and Analysis of Agronomic Research Experiments. Michigan State Univ. U.S.A.

Rahnama, A. and A. Bakhshandeh (2006). Determination of optimum row-spacing and plant density for unbranched sesame in Khuzestan province. J. Agric. Sci. Technol 8: 25-33.

Salame, N.F.; W.M. Bebawi and H.K. Saad (1981). Morphological and correlation studies in peanut. Agric. Res. Rev., 59: 185-200.

Sarkar, R.K. and S.R. Sanyal (2000). Production potential and economic feasibility of sesame (Sesamum Indicum L.) - based intercropping system with pulse and oil seed crops on rice fallow land. Indian J. Agron. 45(3): 545-550.

Sherif, Sahar. A.; A.A. Zohary and Ibrahim, Sahar. T. (2005). Effect of planting dates and densities of maize intercropping with groundnut on growth, yield and yield components of both crops. 
Arab, Univ. J. Agric. Sci., Ain Shams Univ., Cairo, 13(3): 771-791.

Snedecor, G.W. and W.G. Cochran (1988). Statisical Methods $7^{\text {th }}$ Ed. lowa State Univ. Press, Ames,. lowa, U.S.A.

Toaima, S.E.A.; R.A. Atalla and W.A. El-Sawy (2004). Respose of some peanut genotypes to intercropping with sesame in relation to yield and yield components. Annals Agric. Sci. Moshtohor 42(3): 903-916.
Willey, R.W. (1979). Intercropping its importance and research needs. part 1: competition and yield advantages. Field Crops Abst., 32: 1-10.

Willey, R.W. and S.O. Osiru (1972). Studies on mixture of maize and beans (Phasolus vulgaris) with particular reference to plant populations. J. Agric. Sci. Camb. 79: 519-529.

Willey, R.W. and M.R. Rao. (1980). Competitive ratio for quantifying competition between intercrops. Exp. Agric. 16: 117-125. 